\title{
Comparing a simulation model with various analytic models of the
}

\section{international diffusion of consumer technology}

Chris Swinerd, Ken R. McNaught $\$$

Centre for Simulation and Analytics, Cranfield University, Defence Academy of the UK, Shrivenham, Swindon SN6 8LA, UK.

${ }^{\$}$ Corresponding author. Tel: +44(0)1793 785278; Fax: +44(0)1793 782753.

E-mail addresses: c.swinerd@ cranfield.ac.uk (C. Swinerd), k.r.mcnaught@cranfield.ac.uk (K.R. McNaught)

\begin{abstract}
In this paper we propose and evaluate a method for studying technology adoption at the national level using hybrid simulation. A hybrid simulation model is developed which combines elements of system dynamics and agent-based modelling, and treats nations as adopting agents. International diffusion is modelled as a social system where the adoption of an innovation, or even just growing pressure to adopt an innovation, in one nation can then influence its adoption in others. The model is used to investigate nine different technological innovations for which sufficient international data are available. Using the available empirical data, the method of differential evolution is used to configure the model which allows the parameter space to be explored in an efficient manner, without bias or subjective disagreement. Good agreement is found between the parameters derived in this way and those reported to configure analytic models. For each of the nine innovations, we report the rank order correlation between the actual order of adoption of the innovations by nations and the order predicted by the simulation model. We also report the rank order correlations between the actual order and the order predicted by a much simpler statistical model. Improvements in the rank order correlation are shown when some form of social influence between nations is
\end{abstract}


included, although there is no significant difference in results between the four different types of social influence considered by the simulation. The nine technologies investigated also appear to fall into two groups with significantly different uptake speeds. Advantages and limitations of the approach are discussed along with suggested implications for practice.

Key Words: International diffusion, Analytic modelling, Simulation modelling, Agent-based simulation, System Dynamics, Differential evolution 


\section{Introduction}

Research into the diffusion of innovations primarily considers the influence of communication channels over time within a social system comprising defined members [32] who are typically identified as individuals or organisations. However, despite a considerable body of technology diffusion research, relatively little attention has been paid to the case of nation states as the adopting agents. This is perhaps surprising considering the importance of such adoptions which might relate to technological infrastructure, national standards, protocols, etc. Furthermore, many such adoptions at the national level can be significant drivers of social change. In this paper, we focus on modelling the national adoption of various technological innovations. Dekimpe, Parker and Sarvary [9] appear to be the first to explicitly consider the nation state as the adopting agent in their examination of the breadth and depth of cellular technology adoption. Some earlier work had considered it less directly, e.g. Antonelli [2]. While considering the diffusion of modems, he treats nations as adopting agents in one part of his analysis where he examines the diffusion lags of 16 nations. Even fewer publications consider diffusion processes in the context of an international social system of nations, tending to focus instead on in-nation diffusion or the comparison of innation diffusion across nations from which general conclusions are drawn and often described in the context of international diffusion.

Analytic models, and especially epidemic models [15], are used extensively to capture longitudinal and spatial trends, but these models tend to be constrained regarding the extent to which the social system of nations is represented. In this paper a simulation model, as opposed to an analytic model, that combines the system dynamics and agent-based modelling paradigms is introduced. The innovation in this mixed approach is that it allows examination of international diffusion as a 'social' system (where the adoption of a technology in one country can influence its adoption in another) and explores both the temporal and spatial 
dynamics of this process. As such, this work provides a novel contribution to the research domain of innovation diffusion.

\subsection{Simulation as opposed to analytic modelling}

The paradigms of system dynamics (SD) and agent-based (AB) simulation are both well established with much published literature, spanning decades of research. Both have been widely applied across many domains to predict system behaviour using either deductive $\mathrm{SD}$ or inductive $\mathrm{AB}$ approaches (also commonly referred to as top-down and bottom-up approaches, respectively). As such, these paradigms represent complementary approaches to modelling and simulation. Furthermore, each paradigm has its own particular characteristics that make it suitable for modelling certain aspects of systems [41].

Representing resources and dynamics within a system as a set of stocks and flows, SD captures feedback and delay processes to model system behaviour over time. The stocks provide aggregate representations of entities within a system, with flows that are regulated by feedback. Due to the inherent delays, the resultant system behaviour can be non-linear and counter-intuitive. Resource flows correspond to the mean rates at which entities within the system change state. Sterman [35] provides an example of an SD model relevant to the aggregate diffusion process implemented using a modified form of the Bass diffusion model $[3]$.

$\mathrm{AB}$ modelling represents system entities as individuals. Referred to as agents, these entities interact with each other and their environment according to rules which are often simple and local in nature and from which higher level system behaviour can be generated. Facilitated by the advent of object-orientated programming and implemented using asynchronous programming techniques, agent interactions are usually defined by a set of decision-making rules with the agents given sufficient autonomy to interact with each other 
and the environment such that temporal and spatial macro behaviours (aggregated behaviour at a level higher than that of the rules allocated to agents) can be generated and observed. Rixen and Weigand [31] provide an example of $\mathrm{AB}$ simulation modelling for the diffusion of smart meters.

Simulation provides a tool for formally testing a dynamic hypothesis and determining its adequacy [18]. In contrast to a simulation approach, most studies of the international diffusion of innovation use analytic models. These mathematical models tend to use a regression model in which proxy measures are often used as the covariates of operational parameters in order to represent behaviour or attitudes (national characteristics). Analytic models are useful for capturing the structure of diffusion processes, but, unlike simulation modelling, cannot capture adaptive behaviour so easily.

In reviewing innovativeness and adopter categories, Rogers [32] identifies 26 generalisations covering social, economic and environmental factors which affect individuals or organisations within the social system. These factors help determine the responses of members of the social system to innovation, especially regarding its timing and their willingness to adopt, categorising members of a social system as innovators, imitators or laggards. Analytic models tend to use proxy measures to represent such generalisations and, therefore, to represent and identify national characteristics that are key to diffusion processes.

Whilst the observations of Simon [34] (p. 62) appear to support the use of aggregate measures within models to represent key national characteristics, we consider whether a social system comprising a set of nations can be represented in a richer way, using a hybrid simulation approach, than is possible with analytic models.

\section{Literature review}

A review of studies explicitly reporting models for the international diffusion of technology is summarised in Tables 1 and 2. As can be seen, there is a range of proxy 
measures used to describe the characteristics of nations, drawing mainly from physical and human geography; the choice of proxies is often accompanied by arguments as to their suitability.

Based on the references included here and the wider literature, we identify five internal characteristics and use these in the tables to categorise the use of proxy measures. This is not intended as an authoritative categorisation, but is a compromise representing the diversity of measures used across studies and the arguments made for their inclusion. Islam and Meade [21] also use five characteristics: economic activity; access to information; culture and innovation; economic and ethnic heterogeneity; and demographics. The five characteristics used here are similar but allow for the inclusion of national dogma, represented here as the characteristic of authority and law. The tables also represent the scope of cited studies, describing the number of nations included, $m$, along with the technologies and timeframes considered.

Recognising that reasoned action is a mix of intrinsic intent and external influence [12], the difference between those studies represented in Table 1 and those represented in Table 2 is the manner in which external influence upon nations is represented. Those in Table 2 incorporate specific measures of social interaction whereas those in Table 1 do not.

In order to highlight this difference, the work of Gatignon, Eliashberg and Robertson [14] (GER) is introduced as an example from Table 1 with the proposed extension to this model by Kumar, Ganesh and Echambadi [23] (KGE) as an example from Table 2.

In discrete form, GER define their diffusion model as:

$$
S(i, t)-S(i, t-1)=[p(i)+q(i) \times S(i, t-1)] \times[1-S(i, t-1)]+u(i, t)
$$

where $S(i, t)$ is the cumulative penetration of an innovation in a nation $i$ at time $t$, the propensity of a nation to innovate is given by $\mathrm{p}(\mathrm{i})$ and to imitate by $\mathrm{q}(\mathrm{i})$ (sometimes referred to as internal and external influence, respectively) and $u(i, t)$ is a disturbance term. It is 
through these coefficients that the characteristics of nations are captured using weighted proxies, Z(i), of national characteristics:

$$
\begin{aligned}
& \mathrm{p}(\mathrm{i})=\mathrm{Z}^{\prime}(\mathrm{i}) \times \mathrm{g}_{\mathrm{p}}(\mathrm{i})+\mathrm{e}_{\mathrm{p}}(\mathrm{i}) ; \text { and } \\
& \mathrm{q}(\mathrm{i})=\mathrm{Z}^{\prime}(\mathrm{i}) \times \mathrm{g}_{\mathrm{q}}(\mathrm{i})+\mathrm{e}_{\mathrm{q}}(\mathrm{i}),
\end{aligned}
$$

where $\mathrm{g}(\mathrm{i})$ is a weight and e(i) is a disturbance term. This form of regression model can be used to analyse important characteristics associated with innovation diffusion within a nation. A comparison across nations is used to make generic observations or to differentiate national behaviour. However, this model does not explicitly capture interactions between nations and is, therefore, represented in Table 1.

KGE propose an extension to this model including a time lag relative to the 'lead nation', i.e. the first nation to adopt the innovation [5].

$$
\mathrm{q}(\mathrm{i})=\mathrm{Z}^{\prime}(\mathrm{i}) \times \mathrm{g}_{\mathrm{q}}(\mathrm{i})+\tau(\mathrm{i})+\mathrm{e}_{\mathrm{q}}(\mathrm{i}) \text {, }
$$

where $\tau(\mathrm{i})$ is the time lag of nation i relative to the time at which the lead nation adopted. The additional term is applied only to the coefficient of imitation as time lag is not applicable to a nation's propensity to innovate [3]. This modification allows the impact of lag between a nation and the lead nation to be explicitly analysed and, therefore, is represented in Table 2.

Putsis, et al. [30] develop a diffusion model specifically to represent cross-nation mixing. This model stands out from those summarised in Table 2 because it incorporates temporal dynamics as a feature of external national influence as opposed to static measures of bilateral influence. Their model uses proxy measures to represent two parameters - TV sets per capita as a proxy for non-word-of-mouth information and GDP per capita as a proxy for information-seeking and susceptibility. 
Table 1 Proxies used to represent national characteristics in studies of in-nation or comparisons of in-nation diffusion

\begin{tabular}{|c|c|c|c|c|c|c|c|}
\hline \multirow{2}{*}{ Authors } & \multirow{2}{*}{$\begin{array}{l}\text { Scope } \\
m=\text { number of } \\
\text { nations }\end{array}$} & \multirow{2}{*}{$\begin{array}{l}\text { Diffusion } \\
\text { Context }\end{array}$} & \multicolumn{5}{|l|}{ National Characteristic } \\
\hline & & & Wealth, Economics \& Trade & Education \& Information & Ethnicity \& Culture & Authority \& Law & Demographic Profile \\
\hline $\begin{array}{l}\text { Gatignon, Eliashberg } \\
\& \& \text { Robertson } \\
{[14]}\end{array}$ & $\left\{\begin{array}{l}m=14 \\
65-80\end{array}\right.$ & $\begin{array}{l}\text { Dishwasher } \\
\text { Deep Freezzer } \\
\text { Lawn Mower } \\
\text { Pocket } \\
\text { Calculator } \\
\text { Car Radio } \\
\text { Colour TV }\end{array}$ & none & $\begin{array}{l}\text { Mobility(car ownership, cars per inhabitant, } \\
\text { per capita mileage driven) }\end{array}$ & $\begin{array}{l}\text { t, Cosmopolitanism(foreign mail received, foreign mail sent, international } \\
\text { telegrams received, foreign travel, foreign visitors, telephones in use) }\end{array}$ & none & Women in labour force; \\
\hline $\begin{array}{l}\text { Talukar, Sudhir \& } \\
\text { Ainslie } \\
{[42]}\end{array}$ & $\begin{array}{l}m=31 \\
75-97\end{array}$ & $\begin{array}{l}\text { VCR } \\
\text { CD Player } \\
\text { Microwave } \\
\text { oven wav } \\
\text { Camorders } \\
\text { Fax machines } \\
\text { Cellular Ph }\end{array}$ & $\begin{array}{l}\text { PPP/average income; } \\
\text { Imports \& Exports/GDP; }\end{array}$ & $\begin{array}{l}\text { TV ownership; } \\
\text { Newspaper readership; } \\
\text { Illiteracy rate; } \\
\text { Telephone lines; } \\
\text { International phone calls; } \\
\text { Introductory time lag; }\end{array}$ & Number of ethnic groups & none & $\begin{array}{l}\text { Dependants/working people; } \\
\text { GINI index; } \\
\text { Urbanisation; } \\
\text { Woman in labour force; }\end{array}$ \\
\hline$\left[\begin{array}{l}\text { Tellis et al } \\
{[43]}\end{array}\right.$ & $\mid \begin{array}{l}m=16 \\
57-94\end{array}$ & \begin{tabular}{|l} 
Consumer \\
Durables
\end{tabular} & $\begin{array}{l}\text { GDP per capita; } \\
\text { Exports(fo.o..)//apita; } \\
\text { Imports(c.i.f.)/capita }\end{array}$ & $\begin{array}{l}\text { Newspapers per 100; } \\
\text { Radio receivers per 100; } \\
\text { TVs per 100; } \\
\text { Telephones per 100; } \\
\text { Cars per 100; } \\
\text { Third-degree university } \\
\text { students(population); }\end{array}$ & $\begin{array}{l}\text { GINI index/net income; } \\
\text { Masculinity [Hofstede]; } \\
\text { Uncertainty avoidance index [Hofstede]; } \\
\text { Industriousness: ( } \propto 1 / \max \text { monthly temperature); }\end{array}$ & EU membership; & $\begin{array}{l}\text { Female employment or actively } \\
\text { seeking work; } \\
\text { Percentage of Protestants; }\end{array}$ \\
\hline $\begin{array}{l}\text { Neumayer \& Perkins } \\
{[28]}\end{array}$ & $s=135$ & ISO9000 & $\begin{array}{l}\text { Exports of goods and services to EU } \\
\text { export / GDP (export); } \\
\text { Foreign direct investment/GDP; } \\
\text { Manufacturing share of GDP; } \\
\text { GDPPP//size of labour force; } \\
\text { GDPPPP; }\end{array}$ & $\begin{array}{l}\text { Telephone lines per 100; } \\
\text { Secondary school enrolment; }\end{array}$ & none & $\begin{array}{l}\text { Years under European colonial rule; } \\
\text { Index of economic freedom; }\end{array}$ & none \\
\hline $\begin{array}{l}\text { Sunqvist et al } \\
{[38]}\end{array}$ & $\begin{array}{l}m \leq 34 \\
81-00\end{array}$ & $\begin{array}{l}\text { Wireless } \\
\text { Comms }\end{array}$ & GDP per capita; & none & $\begin{array}{l}\text { Masculinity [Hofstede]; } \\
\text { Uncertainty avoidance index [Hofstede]; } \\
\text { (all relative to Sweden or Japan using Morosini et al method) }\end{array}$ & $\begin{array}{l}\text { Individualism [Hofstede]; } \\
\text { Power distance index [Hofstede]; } \\
\text { (all relative to Sweden or Japan using } \\
\text { Morosini et al method) }\end{array}$ & gone \\
\hline $\begin{array}{l}\begin{array}{l}\text { Zhao et al [48] } \\
\text { (Table 4) }\end{array} \\
\end{array}$ & $\begin{array}{l}m=39 \\
95-03\end{array}$ & Internet & $\begin{array}{l}\text { Government expenditure/GDP; or } \\
\text { Energy consumption /GDP; }\end{array}$ & $\begin{array}{l}\text { Literacy } 15 \mathrm{yr}+\text { (population size); or } \\
\text { Labour force with tertiary education; }\end{array}$ & Uncertainty avoidance index [Hofstede]; & $\begin{array}{l}\text { Individualism [Hofstede]; } \\
\text { Power distance index [Hofstede]; } \\
\text { Rule of Law [Kaufmann]; }\end{array}$ & none \\
\hline Hyde [19] & $\begin{array}{l}m=157 \\
60-91 \\
601-06\end{array}$ & \begin{tabular}{|l} 
Election \\
Monitoring
\end{tabular} & $\begin{array}{l}\text { Log GDP; } \\
\text { Log GDP/capita; } \\
\text { US Military aid }\end{array}$ & none & none & $\begin{array}{l}\text { US Cold War Ally(binary); } \\
\text { Democracy-contingent } \\
\text { benefits(\%ODA); } \\
\text { Elections observed in-nation; }\end{array}$ & none \\
\hline $\mid \begin{array}{l}\text { Islam \& Meade } \\
{[21]}\end{array}$ & $\begin{array}{l}m=35 \\
01-09\end{array}$ & $\begin{array}{l}\text { 3G mobile } \\
\text { phone }\end{array}$ & $\begin{array}{l}\text { GDP per capita; } \\
\text { KoF Globalisation Index; }\end{array}$ & $\begin{array}{l}\text { Firms investing in wireless infrastructure; } \\
\text { Innovativeness; }\end{array}$ & $\begin{array}{l}\text { Masculinity [Hofstede]; } \\
\text { Uncertainty avoidance index [Hofstede]; } \\
\text { GIII index; } \\
\text { Number of ethnic groups; }\end{array}$ & $\begin{array}{l}\text { Individualism [Van den Bulte]; } \\
\text { Power distance index [Hofstede]; }\end{array}$ & $\begin{array}{l}\text { Woman in labour force; } \\
\text { Urban population; }\end{array}$ \\
\hline
\end{tabular}


Table 2 Proxies used to represent internal and external national characteristics in studies where specific social dynamics can be explored

\begin{tabular}{|c|c|c|c|c|c|c|c|c|}
\hline \multirow[b]{2}{*}{ Authors } & \multirow{2}{*}{\begin{tabular}{|l|} 
Scope \\
$\mathrm{m}=$ \\
number of \\
nations \\
\end{tabular}} & \multirow[b]{2}{*}{ Diffusion Context } & \multirow[b]{2}{*}{ External National Characteristic } & \multicolumn{5}{|l|}{ Internal National Characteristic } \\
\hline & & & & Wealth, Economics \& Trade & Education \& Information & Ethnicity \& Culture & Authority \& Law & \begin{tabular}{|l|}
$\begin{array}{l}\text { Demographic } \\
\text { Profile }\end{array}$ \\
\end{tabular} \\
\hline \begin{tabular}{|l|} 
Ganesh, Kumar and \\
Subramaniam $[13]$ \\
(dummy variables \\
representing the product \\
also included) \\
\end{tabular} & 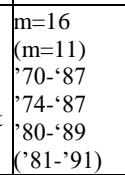 & $\begin{array}{l}\text { VCRs } \\
\text { Microwave ovens } \\
\text { Home PCs } \\
\text { Cellular Ph } \\
\end{array}$ & $\begin{array}{l}\text { Distance between capitals; } \\
\text { Sum of differences(Hofstede); } \\
\text { Sum of differences(GDP, unemployment } \\
\text { rate \& level of urbanisation); } \\
\text { Time lag relative to lead nation }\end{array}$ & none & none & $\begin{array}{l}\text { Coefficients of internal and } \\
\text { external influence }\end{array}$ & none & none \\
\hline Putsis et al [30] & 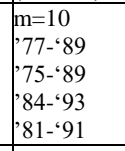 & $\begin{array}{l}\text { VCRs } \\
\text { Microwave ovens } \\
\text { CD Players } \\
\text { Home PCs } \\
\end{array}$ & Mixing parameter & none & $\begin{array}{l}\text { TV sets/capita; } \\
\text { GDP/capita }\end{array}$ & none & none & none \\
\hline $\begin{array}{l}\text { Kumar, Ganesh and } \\
\text { Echambadi [23] }\end{array}$ & \begin{tabular}{|l|l|}
$\mathrm{m}=14$ \\
$\cdot 70-990$ \\
\end{tabular} & $\begin{array}{l}\text { As above plus cellular } \\
\text { phones }\end{array}$ & Time lag relative to lead nation & none & $\begin{array}{l}\text { Mobility ([14]); } \\
\text { Cosmopolitism ([14]); }\end{array}$ & none & none & $\begin{array}{l}\text { Woman in work } \\
\text { force }\end{array}$ \\
\hline \begin{tabular}{|l|} 
Dekimpe et al (model 3) \\
[9]
\end{tabular} & $\begin{array}{l}\mathrm{m}=156 \\
\cdot 79-90\end{array}$ & Cellular Services & $\begin{array}{l}\text { Proportion of adopter nations within own } \\
\text { World Bank group }\end{array}$ & GNP per capita & Time Delay & Number of ethnic groups & \begin{tabular}{|l} 
Dummy variable for former \\
East-bloc nations plus North \\
Korea and Albania \\
\end{tabular} & $\begin{array}{l}\text { Major population } \\
\text { centres; } \\
\text { Population growth }\end{array}$ \\
\hline $\begin{array}{l}\text { Guler, Guillen, \& } \\
\text { MacPherson [17] }\end{array}$ & $\begin{array}{l}\mathrm{m}=85 \\
\text { '93-'98 }\end{array}$ & ISO9000 certification & $\begin{array}{l}\text { Cohesion in trade; } \\
\text { Role equivalence in trade }\end{array}$ & $\begin{array}{l}\text { Inward foreign investment/GDP; } \\
\text { GDP per capita; } \\
\text { Outward foreign investment/GDP }\end{array}$ & Tech Publication/GDP & none & $\begin{array}{l}\text { Government } \\
\text { consumption/GDP; } \\
\text { EU member }\end{array}$ & Size of labour force \\
\hline \begin{tabular}{|l} 
Kumar \& Krishnan \\
{$[24]$}
\end{tabular} & $\begin{array}{l}\mathrm{m}=2 \\
\text { '84-'97 } \\
\mathrm{m}=3 \\
\text { ' } 81-' 97 \\
\mathrm{~m}=4 \\
\text { '74-'97 }\end{array}$ & $\begin{array}{l}\text { CD Player } \\
\text { Cellular Ph } \\
\text { Microwave Oven }\end{array}$ & Coefficient of interaction effect & none & none & $\begin{array}{l}\text { Coefficients of innovation and } \\
\text { imitation }\end{array}$ & none & $\begin{array}{l}\text { Coefficient of } \\
\text { market potential }\end{array}$ \\
\hline \begin{tabular}{|l|} 
Gleditsch \& Ward [16] \\
* Assume taken from \\
http://privatewww.essex. \\
ac.uk/ ksg/statelist.html \\
\end{tabular} & $\begin{array}{l}m \sim 200^{*} \\
\cdot 51-' 98 \\
(1875-' 98)\end{array}$ & Democracy & $\begin{array}{l}\text { Democratic nations within } 500 \mathrm{~km} \text {; } \\
\text { International proportion(democracy) }\end{array}$ & $\begin{array}{l}\text { Log GDP per capita; or } \\
\text { Energy consumption/capita; } \\
\text { Economic growth }\end{array}$ & none & none & $\begin{array}{l}\text { Years at peace; } \\
\text { Time as democracy; } \\
\text { Time as autocracy; }\end{array}$ & none \\
\hline Lee \& Strang [26] & $\begin{array}{l}\mathrm{m}=26 \\
\text { '80-'97 }\end{array}$ & \begin{tabular}{|l} 
Public Sector \\
Downsizing
\end{tabular} & $\begin{array}{l}\text { Network Diffusion (shared border, capital } \\
\text { proximity, trade partnership \& trade } \\
\text { competition); } \\
\text { Learning(economic growth, trade } \\
\text { balances, budgetary health) }\end{array}$ & $\begin{array}{l}\text { Budget Deficit } \\
\text { Trade Balance (import/Export); } \\
\text { GDP Growth Rate }\end{array}$ & none & none & $\begin{array}{l}\text { Government expenditure/GDP; } \\
\text { Left Party Power; } \\
\text { Union Density; } \\
\text { Public Sector Reform } \\
\text { initiatives; } \\
\text { EC Member }\end{array}$ & $\begin{array}{l}\text { Unemployment Rate; } \\
\text { English Speaking }\end{array}$ \\
\hline Shih \& Chang [33] & $\begin{array}{l}\mathrm{m}=48 \\
\cdot 97-' 99\end{array}$ & $\begin{array}{l}\text { Technology } \\
\text { Innovation }\end{array}$ & $\begin{array}{l}\text { Bilateral import of machinery \& } \\
\text { equipment; } \\
\text { International patent citations }\end{array}$ & none & $R \& D$ expenditure & none & none & none \\
\hline
\end{tabular}


There are 8 studies summarised in Table 1 and 9 in Table 2 that, collectively, establish the use of socioeconomic proxies to represent key characteristics of nations. The number of national characteristics included per study is typically 3 or 2 , respectively, suggesting that fewer internal measures are required when external influence is explicitly modelled. The use of the defined national characteristics is fairly even with no clear distinction across the studies represented.

\section{Method}

Based on a recent review of the literature Swinerd [40] and, Swinerd and McNaught [41] draw on published examples from across a wide range of research domains to distil three classes of hybrid AB-SD simulations; these are referred to as integrated, interfaced and sequential. Comprising a number of modules, each of which is implemented in a single modelling paradigm, the design of hybrid models looks to exploit the complementary benefits available from using different approaches and tools.

In the case study of international diffusion discussed here, the aggregate timing of the diffusion process lends itself to the established equation-based rate models, such as the seminal work of Bass [3] and that of Sterman [35]. Patterns of behaviour arising from individual national decision making within a social system of nations, on the other hand, readily lends itself to modelling within an $\mathrm{AB}$ framework. These comprise two modules within our model; each offering known advantages with their respective modelling paradigm, i.e. the representation of temporal and spatial properties, respectively. A third module is used to represent individual national decision making in which equations, representing the fluid rate of change in pressure to adopt a new technology by a nation, are simulated over time. An SD approach is employed in this third module. All of the modules were developed within the 
NetLogo simulation modelling environment [46] which supports both agent-based simulation and system dynamics.

Pressure is considered here as something that is perceived [4] relative to a threshold for action in a defined situation. Within each nation, pressure is measured relative to a decision threshold. As soon as the 'gap' between the pressure experienced and the decision threshold is closed, the nation is assumed to adopt the new technology.

The outline design framework for the model is defined using three modules as presented in Figure 1.

\section{FIGURE 1}

The aggregate diffusion module determines the balance between potential adopter and adopter nations as a function of system age [8]. In accordance with the theory of reasoned action [12], a nation's behavioural intention depends on the weighted sum of the attitude of the individual nation to adopting and the nation's subjective norm related to adopting: subjective norm being a 'mixed-influence' [1] arising from other nations and influencers, such as mass media. At each time step of the aggregate module, the pressure within nations of the $\mathrm{AB}$ module change at a rate determined by the mixed influence of reasoned action. The aggregate process progresses to the next time step only when sufficient nations have adopted within the $\mathrm{AB}$ module. These modules, therefore, represent different scales of the system from the aggregate level down to the individual nation level, each of which can be interrogated to derive output from the model. An overview of the simulation model is presented in Figure 2 where angle brackets differentiate global from local variables and the number of adopters is calculated, following Bass[3], as:

$$
A(t)=(m-A(t-1))(p+q A(t-1))
$$


where $A(t)$ is the number of nations that have adopted by time $t, m$ is the initial number of potential adopting nations, and $\mathrm{p}$ and $\mathrm{q}$ are conventionally defined as the coefficients of innovation and imitation, respectively.

\section{FIGURE 2}

At the highest level, or scale, of the model, time is progressed uniformly in 0.25 year steps. The iteration of change in national pressure uses variable rate steps in order to accommodate the wide range seen in some national measures [39], especially those based on absolute economic performance where there may be orders of magnitude of difference between some nations.

Accumulated pressure over time, Pr, on a nation to adopt depends on internal pressure, $I P$, and on external pressure. Following the terminology used by Abrahamson and Rosenkopf [1], bandwagon pressure, $B P$, will be used to represent external pressure:

$$
\operatorname{Pr}=\int(\mathrm{IP}+\mathrm{BP}) \mathrm{dt}
$$

Consistent with the studies reported in Table 2, the internal contribution to pressure, $I P_{n}$, is represented here as the weighted combination of two national measures:

$$
I P_{n}=W M_{n i}+(1-W) M_{n j}
$$

where the weight $\mathrm{W}$ is a bound model configuration parameter in the range $[0,1]$ and $M_{n i}$ represents the ith normalised selected national measure for nation $n$. Any pairwise combination of national measures is allowed, representing two discrete model configuration parameters $i$ and $j$ for the choice of measures. Each national measure is normalised relative to the maximum value for that measure across all nations, so that it falls in the range $[0,1]$.

Some of the mechanisms which might constitute external influence and so help to create bandwagon pressure are discussed by Beise [5] in the context of mobile telephony. In 
particular, 'transfer advantage' may occur when uncertainty and therefore risks associated with adoption are reduced for remaining nations after the experience of early adopting nations becomes known; or when demand is directly generated for a service in a nonadopting nation by people from other nations which have already adopted the innovation.

Venkatesh, et al. [44] observe that the bandwagon effect is likely to have greater influence earlier in the diffusion process as increasing experience rather than social influence informs individual intention. The level of influence from other nations, $B P$, is, therefore, weighted by an exponential shaping parameter, $r$, in the range $[0,1]$.

Studies of international diffusion covering the periods 1960-1988 [6] and 1980-1997 [26] suggest that geographic proximity is an important determinant of the diffusion process. This is represented in the model by a geographic constraint expressed as the percentage of nations included in a simulation run $(\% G)$ which are allowed to influence each nation; those able to exert influence being selected on the basis of proximity. This geographic constraint is, therefore, a model configuration parameter which we permit to lie in the range $[5 \%, 95 \%]$ defining the number of neighbours, $N$, able to influence any one nation.

Four methods are used to represent social influence between nations. As implemented by Dekimpe, Parker and Sarvary [9], the first considers the proportion of neighbours with influence which have previously adopted:

$$
B P_{n}=\left(\sum_{k=1}^{N_{n}}\left[\frac{A_{k}}{N_{n}}\right]\right)^{\mathrm{r}}, k \neq n
$$

where $N_{n}$ is the number of neighbours able to influence nation $\mathrm{n}$, and $A_{k}$ is an indicator variable, equalling 1 when the kth neighbour of nation $\mathrm{n}$ has adopted the technology, and 0 otherwise.

The second method aims to capture the nature of lead-lag influence as implemented in some models ([5]; [13]; [23]) by using the internal pressure, IP, building within neighbours with influence, regardless of their adoption status, such that: 


$$
B P_{n}=\left(\sum_{k=1}^{N_{n}}\left[\frac{I P_{k}}{N_{n}}\right]\right)^{\mathrm{r}}, k \neq n
$$

In this form, nations need not have adopted the technology in order to exert influence on their neighbours; their growing internal pressure can influence other nations. An example of this may be the growing desire of a nation's population to see national adoption in another non-adopter nation.

These measures of bandwagon pressure are also modified according to the level of structural equivalence, SE, between nations: SE represents the strength of influence between individuals in a social system based on shared social linkages and attributes. Such emulation linked to "cultural similarities" is described, for example, by Lee and Strang [26] (p.903). Also akin to SE, Dekimpe, Parker and Sarvary [9] use the proportion of adopter nations within the same World Bank group as a measure of external influence on a nation. SE weighting between nations has been implemented in models referenced in Table 2 ([9]; [17]; and [33]). Inclusion of SE, therefore, provides two further methods for representing bandwagon pressure:

$$
B P_{n}=\left(\sum_{k=1}^{N_{n}}\left[S E_{k n} \frac{A_{k}}{N_{n}}\right]\right)^{\mathrm{r}}, k \neq n
$$

or, combined with the lead-lag method, as:

$$
B P_{n}=\left(\sum_{k=1}^{N_{n}}\left[S E_{k n} \frac{I P_{k}}{N_{n}}\right]\right)^{\mathrm{r}}, k \neq n
$$

Here, SE is based on international trade import data, reported to be a more accurate reflection of trade than export data [33]. This data was derived using a 10 year static average of bilateral import data (Annual trade figures in \$US) available from the International Monetary Fund [20] covering the period 1990 to 1999. As with most measures of international economics, however, the distribution of wealth has a wide dynamic range: 
therefore, the natural logarithm of the data was used, in a $0.1 \mathrm{~dB}$ resolution, to define $\mathrm{SE}$ weighting in the range $[0.1,0.9]$.

By way of example, the SE weights and associated import trade figures for the UK, Ireland and Fiji are presented in Table 3. In this case the SE weighting is balanced for each nation-pair, which may not always be the case. The $\$ 85 \mathrm{~B}$ imbalance between $\mathrm{UK}$ and Ireland is, however, not sufficient to differentiate SE weighting which indicates the large dynamic range in international trade. With this method, therefore, trading nations with large economies will tend to have higher SE weights compared to those with smaller economies which, in the context of a competitive global market, is assumed reasonable.

\section{Table 3}

SE weights for three nations with associated values of import trade in parentheses

\begin{tabular}{|l|l|l|l|}
\hline & Fiji & Ireland & UK \\
\hline Fiji (Imports) & & $0.5(\$ 0.25 \mathrm{M})$ & $0.7(\$ 17.7 \mathrm{M})$ \\
\hline Ireland (Imports) & $0.5(\$ 0.1 \mathrm{M})$ & & $0.9(\$ 11.2 \mathrm{~B})$ \\
\hline UK (Imports) & $0.7(\$ 122 \mathrm{M})$ & $0.9(\$ 96.2 \mathrm{~B})$ & \\
\hline
\end{tabular}

Bilateral trade data for 196 nations has been incorporated in the model. Of the potential 38220 measures, data was available for 23948; where no data was available, an SE weighting of 0.1 was allocated.

By combining a basic representation of social influence with the presence or absence of both a Structural Equivalence effect and a Lead-Lag effect, four variants of social influence are considered during the simulation runs. These are labelled in Table 6.

In order to investigate the relative importance of internal pressure versus bandwagon pressure, the rate at which accumulated pressure to adopt, $\mathrm{Pr}$, increases is represented as the weighted combination of each. This rate, $R p$, is, therefore, defined as:

$$
R_{p}=I P(1+W P . B P) .
$$


The weighting, $W P$, is a model configuration parameter which we permit to lie in the range $[0,2]$.

\subsection{Performance baseline and the selection of national measures}

In order to help determine the performance of this model, a comparison is made with a baseline that accounts for internal pressure only. This baseline, therefore, predicts the order of national adoption by using a weighted sum of two national measures. Published works often discuss the care required when using such measures as they can exhibit strong correlation between measures ([13]; [17]; [21] and [22]), and with the diffusion process itself ([10]; [16]; [26] and [48]). Accounting for such factors, the initial 42 national measures drawn from the World Bank's dataBank [47] for potential use in the simulation, were reduced to 31 as described at Annex A. Looking to maximise the number of nations represented in simulation runs, all five national characteristics as defined in Table 1 and Table 2 are represented with 6 measures covering wealth, economics and trade (WE\&T), 13 covering education and information (E\&I), 2 covering ethnicity and culture (E\&C), 3 covering authority and law (A\&L) and 7 covering demographics (DP).

As introduced in Table 4, nine technologies are considered for which the year of national adoption is known for between 70 and 209 nations.

\section{Table 4}

Chronological list of technologies considered and associated maximum sample size

\begin{tabular}{|l|l|l|l|}
\hline Technology & Acronym & First Adopted & Number of Nations \\
\hline Video Cameras & VCR & 1977 & 70 \\
\hline Mobile Telephones & MP & 1980 & 205 \\
\hline Satellite TV & satTV & 1981 & 80 \\
\hline Compact Disc Player/Recorder & CD & 1982 & 70 \\
\hline Personal Computer & PC & 1983 & 85 \\
\hline $\begin{array}{l}\text { Integrated Services Digital } \\
\text { Network }\end{array}$ & ISDN & 1988 & 143 \\
\hline Fixed Internet & FIN & 1990 & 209 \\
\hline Digital Versatile Disc & DVD & 1994 & 85 \\
\hline Fixed Broadband & FBB & 1998 & 209 \\
\hline
\end{tabular}


The year in which a nation adopts a technology is defined as that year for which user numbers are first reported in either Euromonitor Global Market Information Database [11] or the World Bank dataBank [47]. Although not considered here, it may be more appropriate to define the year of adoption as the year in which 'takeoff' for that nation was achieved [43]; products reaching 'takeoff' at an average market penetration of $2.5 \%-3 \%$.

Plotted as a function of system age [8], the international diffusion curves for the nine technologies are presented in Figure 3. These curves all reach $100 \%$ since they represent the diffusion process for those nations for which the year of adoption is known.

\section{FIGURE 3}

When assessing the performance of the model, the time frame covering the actual nations represented within a simulation run is used. This may be fewer nations than indicated in Table 4 due to limitations in the availability of data across nations for a specific technology and the two selected national measures. With the exception of PCs (for which early diffusion data is not yet available), it is interesting to observe that the diffusion of these technologies when represented at the national level as in Figure 3, seems to fall into two groups. In one, the maximum rate of diffusion is realised much sooner than in the other. One possible explanation is that international diffusions of this type are generally speeding up since the three most recently introduced technologies (FIN, DVD and FBB in Table 4) belong to the group of four technologies displaying this faster uptake. Another possibility is that the first group represents upgrade technologies and, therefore, adoption is faster based on previous experience and understanding of the value of predecessor technologies. This could also lend support to Davies' [7] categorization of innovations into two types distinguished by their 
complexity. This is clearly an interesting observation in its own right despite the fact that it stems from a static analysis of the dataset rather than from the simulation model

The fitness value used to assess the performance of the model is the non-parametric measure of rank order correlation, $\mathrm{r}_{\mathrm{s}}$, between simulated and actual year of national adoption. In order to maximize sample size, a static average of national measures reported over the period 1980 to 2009 is used, which aligns to the timing of global diffusion for most of the technologies considered here. Whilst the use of a static average is a limitation that does not reflect temporal changes within nations, possibly important for nations with rapid socioeconomic development, for example, this does increase the number of nations represented in the analysis.

In order to assess the performance of the simulation model, and especially the influence of social dynamics, a baseline measure of rank order correlation between IP only and the actual year of adoption (AyrAd), $r_{s}(I P, A y r A d)$, was calculated. This assessment is based on identifying the best weighted pairwise combination of two national measures, $M_{1}$ and $M_{2}$ in order to provide a simple comparative baseline for each technology, as described in Table 5.

\section{Table 5}

Baseline national measures for each technology

\begin{tabular}{|l|l|l|l|l|l|l|l|}
\hline Technology & $\mathrm{r}_{\mathrm{s}}$ & $\mathrm{m}$ & $\mathrm{W}$ & $\mathrm{M}_{1}$ & Description & $\mathrm{M}_{2}$ & Description \\
\hline Video Cameras & 0.660 & 42 & 0.3 & 6 & $\begin{array}{l}\text { Poverty headcount ratio at } \\
\text { \$1.25 a day (PPP) } \% \text { of } \\
\text { population) }\end{array}$ & 9 & $\begin{array}{l}\text { Population Growth } \\
\text { (annual \%) }\end{array}$ \\
\hline Mobile Telephones & 0.862 & 53 & 0.2 & 30 & $\begin{array}{l}\text { Daily newspapers (per } \\
1,000 \text { people) }\end{array}$ & 34 & $\begin{array}{l}\text { Roads, passengers } \\
\text { carried (million } \\
\text { passenger-km) }\end{array}$ \\
\hline Satellite TV & 0.841 & 38 & 0.5 & 30 & $\begin{array}{l}\text { Daily newspapers (per } \\
1,000 \text { people) }\end{array}$ & 34 & $\begin{array}{l}\text { Roads, passengers } \\
\text { carried (million } \\
\text { passenger-km) }\end{array}$ \\
\hline $\begin{array}{l}\text { Compact Disc } \\
\text { Player/Recorder }\end{array}$ & 0.782 & 38 & 0.1 & 30 & $\begin{array}{l}\text { Daily newspapers (per } \\
1,000 \text { people) }\end{array}$ & 34 & $\begin{array}{l}\text { Roads, passengers } \\
\text { carried (million } \\
\text { passenger-km) }\end{array}$ \\
\hline Personal Computer & 0.886 & 68 & 0.2 & 30 & $\begin{array}{l}\text { Daily newspapers (per } \\
1,000 \text { people) }\end{array}$ & 39 & $\begin{array}{l}\text { Telephone lines (per } \\
100 \text { people) }\end{array}$ \\
\hline $\begin{array}{l}\text { Integrated Services } \\
\text { Digital Network }\end{array}$ & 0.827 & 91 & 0.8 & 19 & $\begin{array}{l}\text { Trademark applications, } \\
\text { total }\end{array}$ & 30 & $\begin{array}{l}\text { Daily newspapers (per } \\
1,000 \text { people) }\end{array}$ \\
\hline
\end{tabular}




\begin{tabular}{|l|l|l|l|l|l|l|l|}
\hline Fixed Internet & 0.845 & 96 & 0.9 & 3 & $\begin{array}{l}\text { Total reserves (includes } \\
\text { gold, current US\$) }\end{array}$ & 16 & $\begin{array}{l}\text { Researchers in R\&D } \\
\text { (per million people) }\end{array}$ \\
\hline Digital Versatile Disc & 0.928 & 12 & 0.9 & 7 & $\begin{array}{l}\text { Net income (BoP, current } \\
\text { US\$) }\end{array}$ & 14 & $\begin{array}{l}\text { CPIA gender equality } \\
\text { rating (1=low to } \\
\text { 6=high) }\end{array}$ \\
\hline Fixed Broadband & 0.801 & 114 & 0.1 & 0 & $\begin{array}{l}\text { Average years of } \\
\text { schooling of adults (aged } \\
15+)\end{array}$ & 3 & $\begin{array}{l}\text { Total reserves } \\
\text { (includes gold, current } \\
\text { US\$) }\end{array}$ \\
\hline
\end{tabular}

Clearly, the results in Table 5 show that high levels of correlation can be achieved by simply employing this baseline. With the exception of Authority and Law, each national characteristic is represented in the baseline results at Table 5, with measures associated with Education and Information the most prominent.

\subsection{Configuration of the Model}

As illustrated in Figure 4, the optimization task was to determine the configuration of the model which maximized the rank order correlation coefficient. A rank order correlation coefficient of 1 would correspond to perfect agreement between the model's predictions and the actual rank order of adoption of each nation for a particular technology. A value close to zero, however, would indicate that the model's predictions were no better than a random sequence.

\section{FIGURE 4}

In order to identify a good model configuration from the parameter space, an approach based on evolutionary algorithms, known as differential evolution (DE), was adopted. As with genetic algorithms, the DE process [36] begins with an initial population of potential simulation configurations (or design points in the language of experimental design) and then updates this population through successive iterations known as generations, by applying an evolutionary process. While genetic algorithms employ a binary representation (analogous to chromosomes) of a solution (design point or model configuration), the DE methodology 
employs vectors of real-valued parameters. Given the nature of the bound configuration parameters for the model, however, population vectors, each representing a configuration of the model, were evolved in accordance with the work of Lampinen and Zelinka [25].

In line with Storn and Price's [36] recommendation, the size of the population, $\mathrm{P}$, was set to 80 , ten times the number of configuration variables. The initial population was then created using Latin Hypercube Sampling [27] in order to ensure that the entire solution space was equitably sampled from the outset. The control parameters $\mathrm{F}$ (amplification of differential variation) and $\mathrm{Cr}$ (probability of mutation) of the DE algorithm were determined through experimentation using the data set for adoption of Compact Disc Player/Recorder technology; the nature of the optimization task is assumed identical for all technologies.

\section{Model Results}

The results of configuring the model by using the DE method are presented in Table 7. The 36 results rows arise from crossing the nine technologies with the four variants used to represent social influence within the simulation. Table 6 contains the key to the labelling format used to describe each variant of social influence employed.

\section{Table 6}

Available representations of social influence.

\begin{tabular}{|l|l|l|l|}
\cline { 3 - 4 } \multicolumn{2}{c|}{} & \multicolumn{2}{|c|}{ Lead-Lag (LL) } \\
\cline { 3 - 4 } \multicolumn{2}{c|}{} & Yes & No \\
\hline \multirow{2}{*}{ Structural Equivalence (SE) } & Yes & SE_LL & SE_11 \\
\cline { 2 - 4 } & No & $11 \_L L$ & $11 \_11$ \\
\hline
\end{tabular}

Details of the best performing configuration for each technology are presented along with the generation in which this was found during the evolutionary process. It can be seen that it took 27 generations on average to find the best configuration which compares satisfactorily to the 40 generation limit imposed. 
Before considering the results in more detail, it is worth noting that the evolutionary search process could have rejected the inclusion of any parameter as the allowed ranges include either a zero contribution or give sufficient scope for the parameter to be discounted (as in the case of the geographic constraint).

\section{Table 7}

Best configuration found for each case by the DE method, together with equivalent baseline model configuration, rank order correlation coefficients and calculations for the Wilcoxon signed rank test.

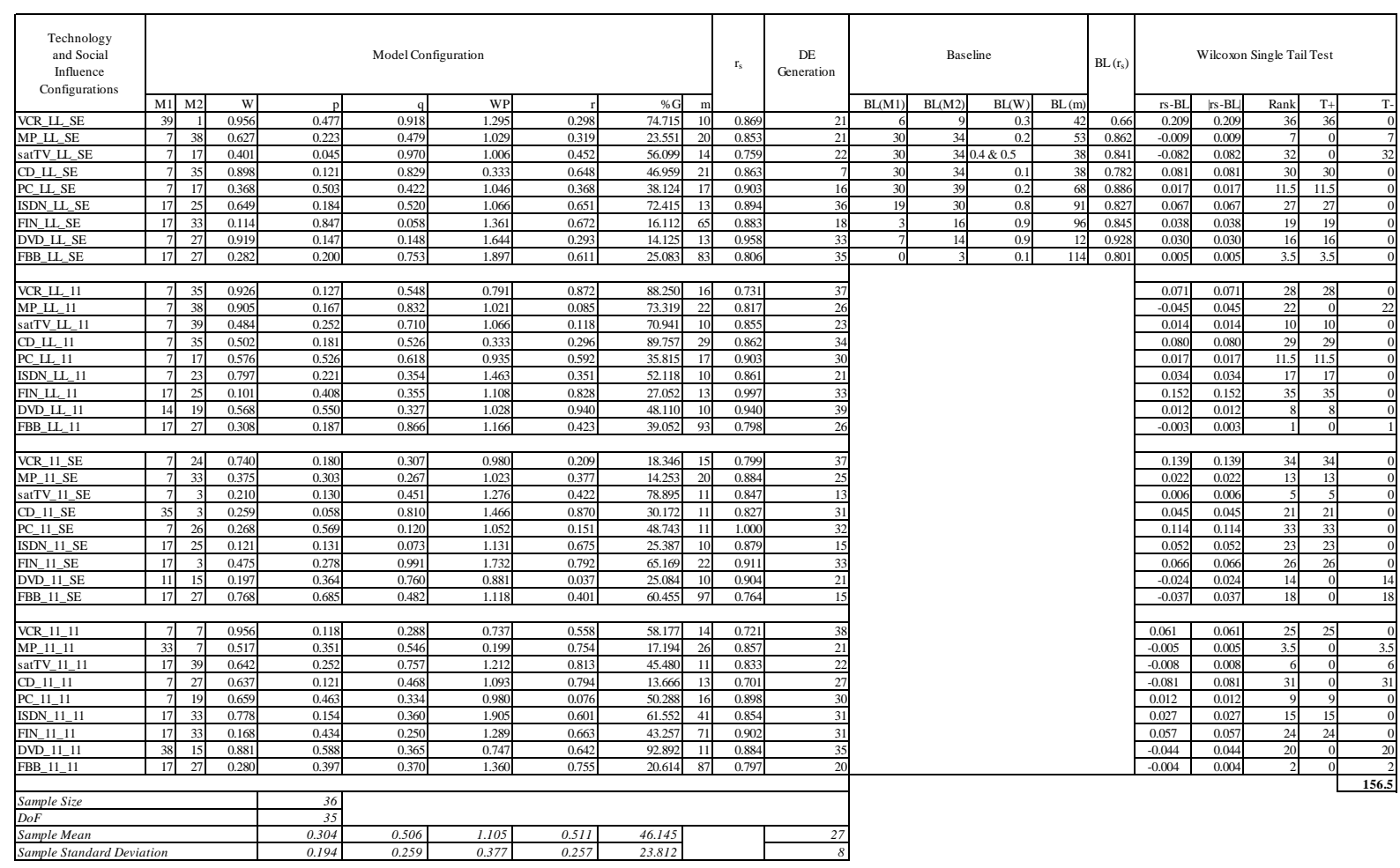

The Wilcoxon signed rank test [45] is used to test the hypothesis that the model is outperforming the corresponding baseline. With the baseline giving high levels of correlation, the model is tested across all 36 simulation runs ( 9 technologies, 4 methods of representing social influence). Operating on the ranked magnitude of differences between the rank correlation coefficient produced by the baseline model and that produced by the simulation model, the Wilcoxon signed rank test returns a test statistic of 156.5. For a 1-tailed test, this is significant at the $0.5 \%$ level (critical value of 171 ). 
A two-way analysis of variance of the simulation results (the rank order correlations) is presented in Table 8. While it is unsurprising that there are significant differences between the nine products, the table also shows that there is no significant difference between results generated by different methods of representing social influence, i.e. the various combinations of structural equivalence and lead lag.

\section{Table 8}

Two-way ANOVA: Response versus Social Influence and Technology Product

\begin{tabular}{|l|l|l|l|l|l|}
\hline Source & DF & SS & MS & F & P \\
\hline Social Influence & 3 & 0.009892 & 0.0032972 & 1.57 & 0.222 \\
\hline Technology Product & 8 & 0.107327 & 0.0134159 & 6.39 & $<10^{-3}$ \\
\hline Error & 24 & 0.050363 & 0.0020985 & & \\
\hline Total & 35 & 0.167582 & & & \\
\hline
\end{tabular}

\section{Discussion}

The Wilcoxon signed rank test shows that the inclusion of social influence produces simulations that outperform the baseline. However, the different ways in which that social influence was represented in the simulation had no additional effect. The parameter WP, which weights the relative contribution of internal and external (bandwagon) pressure to national pressure to adopt takes a mean value of 1.1 across the various technologies, suggesting that these contributions are comparable. The configuration of (internal) national characteristics and then of (external) social influence are, therefore, considered next with reference to the literature.

\subsection{National characteristics}

The national measures selected by the DE process are listed in Table 9. Without $a$ priori selection or bias, the evolutionary search process resulted in a total of 14 national 
measures being employed, two at a time as required by the simulation, across the 36 simulation runs. Net income was the most frequently selected measure (which is not highly correlated [22] with other measures listed at Annex A), and used for all four representations of social influence. This was closely followed by publication of science and technical journal articles (a measure highly correlated with patent applications per capita and passengers carried by road per kilometre), also used in all four representations of social influence. Table 9 contains these 14 measures and shows their frequency of selection and which other measures they are highly correlated with.

All five of the previously suggested national characteristics are represented with measures associated with the characteristic of Education and Information most often used. The least represented characteristics are Ethnicity and Culture and Authority and Law. The greater the frequency with which a national measure is selected, the more robust or useful we can regard that measure as being across the range of cases considered. They are in effect more important in predicting the order of adopting nations for the range of technologies considered. Furthermore, where such a measure is highly correlated with other measures, there is little to be gained by including these other measures as well since their contribution would be largely redundant.

\section{Table 9}

Frequency of use of the 14 national measures selected by the DE process, across the various methods of incorporating social influence, together with other national measures which they are highly correlated with 


\begin{tabular}{|c|c|c|c|c|c|c|c|c|}
\hline $\mathrm{M}$ & LL_SE & LL_11 & 11_SE & $11 \_11$ & Frequency & $\begin{array}{l}\text { Shortened } \\
\text { Description }\end{array}$ & $\begin{array}{l}\text { Correlated } \\
\text { with }\end{array}$ & $\begin{array}{c}\text { National } \\
\text { Characteristic }\end{array}$ \\
\hline 7 & 5 & 6 & 6 & 5 & 22 & Net income & --- & $\begin{array}{c}\text { Wealth, } \\
\text { Economics and } \\
\text { Trade }\end{array}$ \\
\hline 17 & 5 & 3 & 3 & 4 & 15 & \begin{tabular}{|c|}
$\begin{array}{c}\text { Scientific and Technical } \\
\text { Journal Articles }\end{array}$ \\
\end{tabular} & 18,34 & $\begin{array}{c}\text { Education and } \\
\text { Information } \\
\end{array}$ \\
\hline 27 & 2 & 1 & 1 & 2 & 6 & $\begin{array}{c}\begin{array}{c}\text { Normalised International } \\
\text { tourism, arrivals }\end{array} \\
\end{array}$ & 28 & $\begin{array}{c}\text { Authority and } \\
\text { Law } \\
\end{array}$ \\
\hline 35 & 1 & 2 & 2 & 0 & 5 & Population density & --- & Demographics \\
\hline 33 & 1 & 0 & 0 & 3 & 4 & $\begin{array}{l}\text { Railways, passengers } \\
\text { carried }\end{array}$ & --- & $\begin{array}{c}\text { Education and } \\
\text { Information }\end{array}$ \\
\hline 38 & 1 & 1 & 1 & 1 & 4 & Telephone lines & 39 & $\begin{array}{c}\text { Education and } \\
\text { Information }\end{array}$ \\
\hline 39 & 1 & 1 & 0 & 1 & 3 & GDP per capita & --- & $\begin{array}{c}\text { Wealth, } \\
\text { Economics and } \\
\text { Trade } \\
\end{array}$ \\
\hline 25 & 1 & 1 & 1 & 0 & 3 & $\begin{array}{c}\text { Labor force with } \\
\text { secondary education }\end{array}$ & --- & $\begin{array}{c}\text { Education and } \\
\text { Information } \\
\end{array}$ \\
\hline 19 & 0 & 1 & 1 & 1 & 3 & $\begin{array}{c}\text { Trademark applications, } \\
\text { total }\end{array}$ & 34 & $\begin{array}{c}\text { Education and } \\
\text { Information }\end{array}$ \\
\hline 23 & 0 & 1 & 1 & 0 & 2 & $\begin{array}{c}\text { Expenditure per student, } \\
\text { tertiary }\end{array}$ & --- & $\begin{array}{c}\text { Education and } \\
\text { Information }\end{array}$ \\
\hline 14 & 0 & 1 & 1 & 0 & 2 & $\begin{array}{l}\text { CPIA gender equality } \\
\text { rating }\end{array}$ & --- & $\begin{array}{c}\text { Ethnicity and } \\
\text { Culture }\end{array}$ \\
\hline 1 & 1 & 0 & 0 & 0 & 1 & Literacy Rate & 2 & $\begin{array}{c}\text { Education and } \\
\text { Information }\end{array}$ \\
\hline 11 & 0 & 0 & 1 & 0 & 1 & \begin{tabular}{|c|}
$\begin{array}{c}\text { Urban Population (\% of } \\
\text { total) }\end{array}$ \\
\end{tabular} & --- & Demographics \\
\hline 15 & 0 & 0 & 0 & 1 & 1 & $\begin{array}{c}\text { CPIA property rights and } \\
\text { rule-based governance } \\
\text { rating }\end{array}$ & --- & $\begin{array}{l}\text { Ethnicity and } \\
\text { Culture }\end{array}$ \\
\hline
\end{tabular}

A cross-study comparison of the use of national measures is presented in Tables 10 and 11, comparing, where possible, the configuration of this simulation model with measures reported as significant in the studies represented in Tables 1 and 2, respectively. In Tables 10 and 11, the rightmost 14 columns correspond to the 14 national measures selected by the DE process to feature in at least one of the best simulation configurations over the 36 cases. A filled cell indicates that such a measure was also employed in one of the studies shown in the first column. Comparisons are shown, with reference to Table A1 at Annex A, only where the 
same, or very similar, national measures are used. The symbol '=>' used in Tables 10 and 11 indicates high positive correlation between the measure adopted in this work and that reported by the relevant study in the table. Of the 33 rows in Table 10, corresponding to the total number of national measures used by the studies listed in the first column, 17 rows contain a filled cell. Of the 12 rows in Table 11, 11 rows contain a filled cell. Agreement on the type of national measure considered important is, therefore, much greater for the second set of studies. This is most likely because the second set of studies were closer in context to the international situations considered by the simulation. 
Table 10 Comparing the utilisation of national measures with studies categorised in Table 1 (numbers in the table correspond to the numbering

of national measures in Table 9).

\begin{tabular}{|c|c|c|c|c|c|c|c|c|c|c|c|c|c|c|c|c|c|}
\hline Authors & $\begin{array}{l}\text { National } \\
\text { Characteristic }\end{array}$ & Significant Proxies & Validation & 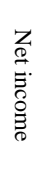 & 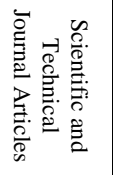 & 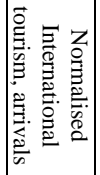 & 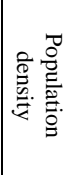 &  & 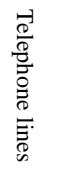 & 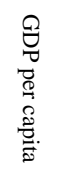 & 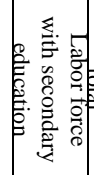 & 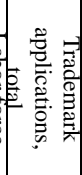 & 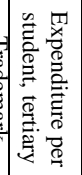 & 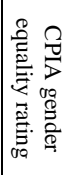 & & 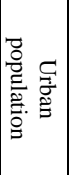 & 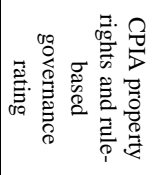 \\
\hline \multirow{4}{*}{$\begin{array}{l}\text { Gatignon, Eliashberg \& } \\
\quad \text { Robertson [14] }\end{array}$} & E\& I & Mobility: per capita mileage driven & significant & & $17=>34$ & & & & & & & & & & & & \\
\hline & \multirow{3}{*}{$\mathrm{E} \& \mathrm{C}$} & Cosmopolitanism: foreign travel & significant & & & \multirow{2}{*}{27} & & & & & & & & & & & \\
\hline & & Cosmopolitanism: foreign visitors & significant & & & & & & & & & & & & & & \\
\hline & & Cosmopolitanism: telephones in use & significant & & & & & & 38 & & & & & & & & \\
\hline \multirow{7}{*}{$\begin{array}{l}\text { Talukar, Sudhir \& Ainslie } \\
\text { [42] }\end{array}$} & \multirow{3}{*}{$\mathrm{W}, \mathrm{E}, \& \mathrm{~T}$} & PPP/average income (All products) & significant & 7 & & & & & & & & & & & & & \\
\hline & & Imports / GDP (All products) & lower priority & & & & & & & & & & & & & & \\
\hline & & Exports / GDP (All products) & lower priority & & & & & & & & & & & & & & \\
\hline & \multirow[t]{2}{*}{ E \& I } & $\begin{array}{l}\text { Newspaper readership (Not consumer products } \\
\text { only) }\end{array}$ & lower priority & & & & & & & & & & & & & & \\
\hline & & Illiteracy rate (All products) & lower priority & & & & & & & & & & & & & & \\
\hline & \multirow{2}{*}{ D P } & GINI index (Consumer products only) & lower priority & & & & & & & & & & & & & & \\
\hline & & Urbanisation(All products) & significant & & & & & & & & & & & & & 11 & \\
\hline \multirow{8}{*}{ Tellis et al [43] } & \multirow{3}{*}{$\mathrm{W}, \mathrm{E}, \& \mathrm{~T}$} & GDP per capita & significant & & & & & & & 39 & & & & & & & \\
\hline & & Exports / capita & lower priority & & & & & & & & & & & & & & \\
\hline & & Imports / capita & lower priority & & & & & & & & & & & & & & \\
\hline & \multirow{4}{*}{ E \& I } & Newspapers / 100 & lower priority & & & & & & & & & & & & & & \\
\hline & & Telephones / 100 & significant & & & & & & 38 & & & & & & & & \\
\hline & & Cars / 100 & significant & & & & & & & & & & & & & & \\
\hline & & Third-degree university students & significant & & & & & & & & & & 23 & & & & \\
\hline & $\mathrm{A} \& \mathrm{~L}$ & no significant proxies reported & significant & & & & & & & & & & & & & & \\
\hline \multirow{5}{*}{ Neumayer and Perkins [28] } & \multirow{3}{*}{$\mathrm{W}, \mathrm{E}, \& \mathrm{~T}$} & EU Exports / GDP(exports) & lower priority & & & & & & & & & & & & & & \\
\hline & & GDP(PPP) / labor force & significant & & & & & & & 39 & & & & & & & \\
\hline & & GDP (PPP) & significant & & & & & & & 39 & & & & & & & \\
\hline & \multirow{2}{*}{ E \& I } & Telephones / 100 & significant & & & & & & 38 & & & & & & & & \\
\hline & & Secondary school enrolment & significant & & & & & & & & 25 & & & & & & \\
\hline Sunqvist et al [38] & $\mathrm{W}, \mathrm{E}, \& \mathrm{~T}$ & GDP per capita & significant & & & & & & & 39 & & & & & & & \\
\hline \multirow{4}{*}{ Zhao et al [48] } & \multirow{2}{*}{ E \& I } & Literacy $15 \mathrm{yr}+$ (population size) & lower priority & & & & & & & & & & & & 1 & & \\
\hline & & Labour force with tertiary education & significant & & & & & & & & & & & & & & \\
\hline & $\mathrm{E} \& \mathrm{C}$ & Uncertainty avoidance index & not included & & & & & & & & & & & & & & \\
\hline & A \& L & Rule of Law [Kaufmann] & not included & & & & & & & & & & & & & & \\
\hline Hyde [19] & $\mathrm{W}, \mathrm{E}, \& \mathrm{~T}$ & Log GDP per capita & significant & & & & & & & 39 & & & & & & & \\
\hline \multirow{3}{*}{ Islam \& Meade [21] } & $\mathrm{W}, \mathrm{E}, \& \mathrm{~T}$ & GDP / capita & significant & & & & & & & 39 & & & & & & & \\
\hline & E \& I & Firms wireless Infra. & lower priority & & & & & & & & & & & & & & \\
\hline & $\mathrm{E} \& \mathrm{C}$ & GINI index & lower priority & & & & & & & & & & & & & & \\
\hline
\end{tabular}


Table 11 Comparing the utilisation of national measures with studies categorised in Table 2 (numbers in the table correspond to the numbering of national measures in Table 9).

\begin{tabular}{|c|c|c|c|c|c|c|c|c|c|c|c|c|c|c|c|c|c|}
\hline Authors & $\begin{array}{l}\text { National } \\
\text { Characteristic }\end{array}$ & Significant Proxies & Validation & 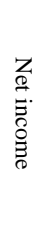 & 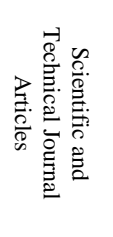 & 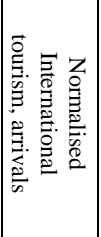 & 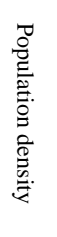 & 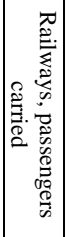 & 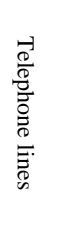 & 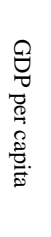 & 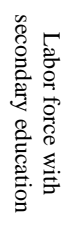 &  & 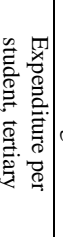 & 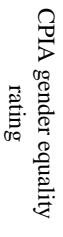 & 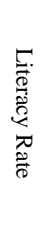 &  & 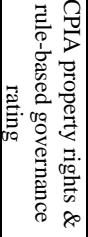 \\
\hline Putsis, et al. [30] & $\mathrm{W}, \mathrm{E}, \& \mathrm{~T}$ & GDP / capita & significant & & & & & & & 39 & & & & & & & \\
\hline \multirow{4}{*}{ Kumar, Ganesh and Echambadi [23] } & E\& I & Mobility: per capita mileage driven & significant & & $17=>34$ & & & & & & & & & & & & \\
\hline & \multirow{3}{*}{$\mathrm{E} \& \mathrm{C}$} & Cosmopolitanism: foreign travel & significant & & & \multirow{3}{*}{27} & & & & & & & & & & & \\
\hline & & Cosmopolitanism: foreign visitors & significant & & & & & & & & & & & & & & \\
\hline & & Cosmopolitanism: telephones in use & significant & & & & & & 38 & & & & & & & & \\
\hline \multirow{2}{*}{ Dekimpe, et al. (model 3) [9] } & $\mathrm{W}, \mathrm{E}, \& \mathrm{~T}$ & GNP / captia & significant & & & & & & & 39 & & & & & & & \\
\hline & D P & Major population centres & significant & & & & 11 & & & & & & & & & 35 & \\
\hline \multirow{2}{*}{ Guler, Guillen and McPherson [17] } & $\mathrm{W}, \mathrm{E}, \& \mathrm{~T}$ & GDP / capita & significant & & & & & & & 39 & & & & & & & \\
\hline & E \& I & Technical Publications / GDP & significant & & 17 & & & & & & & & & & & & \\
\hline Gleditsch and Ward [16] & $\mathrm{W}, \mathrm{E}, \& \mathrm{~T}$ & Log GDP / captia & significant & & & & & & & 39 & & & & & & & \\
\hline Lee and Strang [26] & $\mathrm{W}, \mathrm{E}, \& \mathrm{~T}$ & GDP & significant & & & & & & & 39 & & & & & & & \\
\hline Shih and Chang [33] & E \& I & R\&D Expenditure & lower significance & & & & & & & & & & & & & & \\
\hline
\end{tabular}




\subsection{Social influence}

The mean value of the exponential shaping parameter, $r$, across the various technologies is close to 0.5 . This indicates that social influence is more important early in the diffusion process, supporting Venkatesh, et al. [44]. However, the results here extend that observation to the influence between nations with regard to the adoption of technology.

The mean value obtained for the geographic constraint on social influence across the various technologies, $\% \mathrm{G}$, is $46 \%$ which suggests that even though the world is increasingly interconnected, geographic proximity can still be important to a nation's timing for adopting technology, consistent with [6] and [26].

Three of the technologies considered here were first adopted in the 1990s (FIN, FBB and DVD). In order to assess whether the geographic constraint parameter, \%G, is different for these versus the rest, a Mann-Whitney $U$ test was conducted. The result from this shows that the difference in $\% \mathrm{G}$ between the two groups is not statistically significant at the $5 \%$ level.

Configuration values for the coefficients of innovation and imitation, $p$ and $q$, average 0.304 and 0.506 , respectively, across all simulations. Of the four technologies displaying faster uptake, however, the $\mathrm{CD}$ appears to be anomalous, at least with respect to the two possible explanations which we have offered for the observed difference, since the CD is not an upgrade technology and its introduction was much earlier than the others in the fast uptake group. For the three remaining technologies (FIN, DVD and FBB) in the fast uptake group, mean values of the coefficients $p$ and $q$ are 0.424 and 0.477 , respectively, while for the other six technologies considered, the mean values of $\mathrm{p}$ and $\mathrm{q}$ are 0.244 and 0.521 , respectively. Two-sample t-tests were performed on the values of $\mathrm{p}$ and $\mathrm{q}$ derived from the simulation. These show that while the difference in $p$, the coefficient of innovation, between these two groups is statistically significant at the $5 \%$ level, the difference in $\mathrm{q}$, the coefficient of 
imitation, is not statistically significant at this level. This is consistent with the view that imitation remains the same whereas propensity to innovate increases where adoption risk has been reduced by knowledge of a preceding technology.

\section{Conclusions}

In this paper we have investigated an important type of diffusion but one which appears to have been largely neglected in the literature, that of technology adoption at the national level. Nine technologies were examined, covering the time period 1977 to 2009 . A novel aspect of this work is the use of a hybrid simulation comprising both agent-based and system dynamics modules to model the diffusion process and to represent nations as agents within a social system. In this simulation model, social influence between nations was moderated over time and represented by bilateral trade (import) and geographic proximity. A major focus of our work was to compare the use of simulation with analytic models for representing the diffusion of technologies among nations. In general, simulation models offer greater flexibility and richer output than analytic models.

The choice of parameters to configure the simulation model in order to provide a good fit to the observed data was guided by a heuristic procedure called differential evolution; similar in principle to genetic algorithms. The fitness measure employed was the rank correlation coefficient between the actual and simulated year of adoption of the technology in question among the set of nations for which the relevant data were available. We believe that such an approach to parameterising a diffusion model is also novel. Furthermore, the choices of variables and values generated by the DE process were largely consistent with the published literature regarding international technology diffusion. This may encourage other diffusion researchers to adopt an evolutionary approach such as DE in parameterising their 
models, particularly where prior knowledge is limited or there is substantial disagreement on the most appropriate measures to use.

Use of the one-tailed Wilcoxon signed rank test, covering the nine technologies and four representations of social influence considered, demonstrates that the simulation model outperforms the best weighted pairwise combination of the forty-two national measures considered. However, while inclusion of some form of social influence enhances the performance of the model, statistical analysis using analysis of variance reveals that there is no significant difference regarding the format of social influence used in this case. In fact, this may be because the baseline model was already performing well and so only a limited amount of improvement in the rank order correlation coefficient was possible. While incorporating any form of social influence leads to some improvement, achieving yet further improvements by distinguishing between different types of social influence is very difficult since the correlation coefficients are already close to 1 . However, this does not mean that such differentiation could not be useful in another simulation with different performance measures.

An interesting observation from this work is the apparent difference in uptake speed between two groups of technologies and we have suggested two possible explanations for this: how recently the technology was introduced and whether it could be regarded as an upgrade of an existing technology. Further research covering a much greater number of technologies is required to investigate this further. If national adoption is usually faster for upgrade technologies, then technology suppliers should be aware of this difference since if speed of uptake is of concern to them, it may not be necessary to offer financial or other inducements to incentivise adoption of upgrades. Such incentives may be better targeted at encouraging the adoption of genuinely new technologies. Suppliers may also wish to avoid 
creating greater demand for an upgrade technology than they can deliver since in some cases this may simply create opportunities for their competitors to exploit.

The benefit of using simulation modelling compared to analytic modelling is that dynamic behaviours can be incorporated and investigated more easily. Having introduced a simulation model and shown how its configuration compares with a number of published analytic models, the next step is to investigate whether dynamic behaviours can be isolated and compared with observed patterns of adoption.

One limitation of this study was the use of indicators averaged over several years instead of dynamic or at least annual data. It was also limited in the number and type of technologies examined, largely due to the availability of data. While we believe that predictions regarding the order of adoption of particular technologies by nations would be of interest and value to market analysts and global suppliers of these technologies, richer model output may be required in order for these organizations to achieve maximum benefit from such an approach. In future work we will consider such requirements and the feasibility of fulfilling them with simulation models.

\section{Acknowledgments}

The authors would like to thank the anonymous referees for their valuable and constructive comments which have helped to improve the focus and clarity of this paper.

\section{References}

[1] E. Abrahamson, L. Rosenkopf, Social network effects on the extent of innovation diffusions: a computer simulation, Organization Science 8(3) (1997) 289-309.

[2] C. Antonelli, The international diffusion of new information technologies, Research Policy, 15(3) (1986) 139-147. 
[3] F.M. Bass, A new product growth model for consumer durables, Management Science 15(5) (1969) 215-227.

[4] S. Beilock, Choke: What the Secrets of the Brain Reveal About Getting it Right When You Have to. New York: The Free Press, 2010.

[5] M. Beise, Lead markets: country-specific drivers of the global diffusion of innovations. Research Policy 33(6-7) (2004) 997-1018.

[6] C.S. Craig, S.P. Douglas, A. Grein. Patterns of convergence and divergence among industrialised nations: 1960 - 1988. Journal of International Business Studies; Fourth Quarter 1992; 23(4) (1992) 773-787.

[7] S.W. Davies, The Diffusion of Process Innovations, Cambridge University Press, Cambridge, 1979.

[8] M.G. Dekimpe, P.M. Parker, M. Sarvary, Staged estimation of international diffusion models: an application to global cellular telephone adoption. Technol. Forecast. Soc. Change 57 (1998) 105-132.

[9] M.G. Dekimpe, P.M. Parker, M. Sarvary, “Globalization”: modeling technology adoption timing across countries. Technol. Forecast. Soc. Change 63 (2000) 25-42.

[10] J. Eaton, S. Kortum, International technology diffusion: theory and measurement. International Economic Review 40(3) (1999) 537-570.

[11] Euromonitor (2012) http://www.euromonitor.com/ [Accessed 2012].

[12] M. Fishbein, I. Ajzen, Belief, Attitude, Intention and Behavior: An Introduction to Theory and Research, Reading, MA: Addison-Wesley Publishing Company, 1975.

[13] J. Ganesh, V. Kumar, V. Subramaniam, Learning effect in multinational diffusion of consumer durables: an exploratory investigation. Journal of the Academy of Marketing Science 25(3) (1997) 214-228. 
[14] H. Gatignon, J. Eliashberg, T.S. Robertson, Modeling multinational diffusion patterns: an efficient methodology. Marketing Science 8(3) (1989) 231-247.

[15] P.A. Geroski, Models of technology diffusion. Research Policy 29 (2000) 603-625.

[16] K.S. Gleditsch, M.D. Ward, Diffusion and the international context of democratization. International Organization 60(4) (2006) 911-933.

[17] I. Guler, M.F. Guillen, J.M. MacPherson, Global competition, institutions, and the diffusion of organizational practices: the international spread of ISO 9000 quality certificates. Administrative Science Quarterly 47(2) (2002) 207-232.

[18] J. Homer and R. Oliva, Maps and models in system dynamics: a response to Coyle. System Dynamics Review 17(4) (2001) 347-355.

[19] S.D. Hyde, Catch us if you can: election monitoring and international norm diffusion. American Journal of Political Science 55(2) (2011) 356-369.

[20] International Monetary Fund (2012): Direction of Trade Statistics (Edition: June 2012). ESDS International, University of Manchester. DOI: ttp://dx.doi.org/10.5257/imf/dots/2012-06

[21] T. Islam T, N. Meade, The impact of competition, and economic globalization on the multinational diffusion of 3G mobile phones. Technol. Forecast. Soc. Change 79 (5) (2012) 843-850.

[22] R.J. Kauffman, A.A. Techatassanasoontorn, International diffusion of digital mobile technology: a coupled-hazard state-based approach, Information Technology \& Management 6(2-3) (2005).

[23] V. Kumar, J. Ganesh, R. Echambadi, Cross-national diffusion research: what do we know and how certain are we? Journal of Product Innovation Management 15(3) (1998) 255-268. 
[24] V. Kumar, T.V. Krishnan, Research Note, Multinational diffusion models: an alternative framework. Marketing Science 21(3) (2002) 318-330.

[25] J. Lampinen J, I. Zelinka, “Mixed integer-discrete-continuous optimization with differential evolution." Proceedings of the 5th International Mendel Conference Soft Computing (1999), pp. 71-76.

[26] C.K. Lee, D. Strang D, The international diffusion of public-sector downsizing: network emulation and theory-driven learning. International Organization 60(4) (2006) 883-909.

[27] M.D. McKay, R.J. Beckman, W.J. Conover, A comparison of three methods for selecting values of input variables in the analysis of output from a computer code. Technometrics (American Statistical Association) 21(2) (1979) 239-245.

[28] E. Neumayer, R. Perkins, Uneven geographies of organizational practice: explaining the cross-national transfer and diffusion of ISO 9000. Economic Geography 81(3) (2005) 237-259.

[29] W.H. Press, S.A. Teukolsky, W.T. Vetterling, B.P. Flannery, Numerical Recipes in Fortran. Cambridge University Press 1992.

[30] W.P. Putsis Jr., S. Balasubramanian, E.H. Kaplan, S.K. Sen, Mixing behaviour in cross-country diffusion. Marketing Science 16(4) (1997) 354-369.

[31] M. Rixen, J. Weigand, Agent-based simulation of policy induced diffusion of smart meters. Technol. Forecast. Soc. Change (2013)(In press), http//dx.doi.org/10.1016/j.techfore.2013.08.011

[32] E.M. Rogers, Diffusion of Innovations, 5th ed., New York: The Free Press, 2003.

[33] H-Y Shih, T-L.S. Chang, International diffusion of embodied and disembodied technology: a network analysis approach. Technol. Forecast. Soc. Change 76(6) (2009) 821-834. 
[34] H.A. Simon, The Sciences of the Artificial. Third Edition, MIT Press, 1996.

[35] J.D. Sterman, Business Dynamics: Systems Thinking and Modelling for a Complex World. Irwin/McGraw-Hill: Chicago, 2000.

[36] R. Storn, K. Price, Differential Evolution - A Simple and Efficient Adaptive Scheme for Global Optimization Over Continuous Spaces. Technical Report TR-95-012, ICSI, 1995.

[37] F. Sultan, J.U. Farley, D.R. Lehmann, A meta-analysis of applications of diffusion models. Journal of Marketing Research 27(1) (1990) 70-77.

[38] S. Sundqvist, L. Frank, K. Puumalainen, The effects of country characteristics, cultural similarity and adoption timing on the diffusion of wireless communications. Journal of Business Research 58 (1 SPEC.ISS) (2005) 107-110.

[39] C. Swinerd, Simulating the diffusion of technological innovation with an integrated class of hybrid agent-based system dynamics model. Proceedings of the Operational Research Society Simulation Workshop 2012 (SW12): Tjahjono B, Heavey C, Onggo S, and van der Zee D-J, eds.

[40] C. Swinerd, On the design of hybrid simulation models, focussing on the agent-based system dynamics combination, PhD Thesis, Cranfield University, 2014, Available [online]: http://dspace.lib.cranfield.ac.uk/handle/1826/8645 [Accessed November 2014].

[41] C. Swinerd, K.R. McNaught, Design classes for hybrid simulations involving agentbased and system dynamics models, Simulat. Modell. Pract. Theory 20(1) (2012) 118-133; doi:10.1016/j.simpat.2011.09.002.

[42] D. Talukar, K. Sudhir, A. Ainslie, Investigating new product diffusion across products and countries. Marketing Science 21(1) (2002) 97-114. 
[43] G.J. Tellis, S. Stemersch, E. Yin, The international takeoff of new products: the role of economics, culture, and country innovativeness. Marketing Science 22(3) (2003) 188-208.

[44] V. Venkatesh, R.H. Smith, M.G. Morris, G.B. Davis, F.D. Davis, S.M. Walton, User acceptance of information technology: toward a unified view. MIS Quarterly Vol. 27(3) (2003) 425-478.

[45] F. Wilcoxon, Individual comparisons by ranking methods. Biometrics Bulletin 1(6) (1945) 80-83.

[46] U. Wilensky, NetLogo. http://ccl.northwestern.edu/netlogo. Center for Connected Learning and Computer-Based Modeling. Northwestern University, Evanston, IL, 1999.

[47] World Bank, http://databank.worldbank.org/ddp/home.do [Accessed April 2012]

[48] H. Zhao, S. Kim, T. Suh, J. Du, Social institutional explanations of global internet diffusion: a cross-country analysis. Journal of Global Information Management 15(2) (2007) 28-55.

\section{Appendix A - National measures}

In comparing the order of simulated and actual year of national adoption, a nonparametric assessment of the quality of the simulation model can be made using the Spearman rankorder correlation coefficient [29]. The correlations between national measures and the known year of national adoption were assessed using the same approach as described here. Ties, i.e. nations that adopted in the same year, are each assigned a rank that represents the mean of the ranks that would normally be allocated. The rank correlation coefficient, $\mathrm{r}_{\mathrm{s}}$, is derived from the sum of squared differences of ranks [29]. 
Initially, 42 national development indicators (M0 to M41) drawn from the World Bank's dataBank [47] were selected, representing the 26 generalisations identified by Rogers [32] for adopter categories and innovativeness. Where appropriate, these indicators were scaled to avoid unnecessary bias. For example, population growth is expressed as a percentage and, therefore, offers no bias when comparing nations, whereas the number of researchers working in $\mathrm{R} \& \mathrm{D}$, for example, has to be normalised to take account of population size, otherwise nations with significantly different population sizes could not reasonably be compared.

A static average of values reported over the period 1980 to 2009 , which aligns with the adoption timeframe of the technologies considered, is used for each indicator in order to maximise the number of nations represented. The population of nations for a simulation is made up of only those nations which have a recorded value for each of the national development indicators used in that simulation. For ease of model development, the indicators are normalised relative to the maximum value of that indicator among the nations in the population, placing the measures in the range $[0,1]$.

The Spearman rank order correlation coefficient between each pair of measures was calculated and, following Kauffman and Techatassanasoontorn [22], those for which $r_{s}>0.7$, are considered to be highly correlated. Of these highly correlated measures, those which are known for the most number of nations were selected for inclusion in this study. Aligned to each of the five national characteristics defined in Tables 1 and 2, the national measures identified in this way are presented in Table A1. The greyed measures are not included as they are highly correlated with another measure which represents more nations. Those measures shown to be significant in the simulations (Table 9) are shown in bold font.

\section{Table A1}

National measures 


\begin{tabular}{|c|c|c|c|c|c|c|c|c|c|c|c|}
\hline M & $m$ & Char. & Measure & \multicolumn{8}{|c|}{ Measures with which $r_{s}>0.7$} \\
\hline 0 & 113 & E\&I & Average years of schooling of adults (aged 15+) & 1 & 2 & 16 & 26 & 29 & 30 & 38 & 39 \\
\hline 1 & 149 & $\mathbf{E} \& \mathbf{I}$ & Literacy rate & 2 & --- & --- & --- & --- & --- & --- & --- \\
\hline 2 & 124 & $\mathrm{E} \& \mathrm{I}$ & Mean years of schooling & 16 & 30 & --- & --- & --- & --- & --- & --- \\
\hline 3 & 184 & WE\&T & Total reserves (includes gold, current US\$) & 17 & 19 & 34 & --- & --- & --- & --- & -- \\
\hline 4 & 127 & WE\&T & Present value of external debt (current US\$) & --- & --- & --- & --- & --- & --- & --- & --- \\
\hline 5 & 170 & WE\&T & Gross savings ( $\%$ of GDP) & --- & --- & --- & --- & --- & --- & --- & --- \\
\hline 6 & 118 & $\mathrm{DP}$ & Poverty headcount ratio at $\$ 1.25$ a day (PPP) (\% of population) & 27 & 28 & 29 & 30 & 38 & 39 & --- & --- \\
\hline 7 & 183 & WE\&T & Net income (BoP, current US\$) & -- & -- & -- & --- & --- & -- & --- & -- \\
\hline 8 & 146 & DP & GINI Index & --- & --- & --- & --- & --- & --- & --- & -- \\
\hline 9 & 205 & DP & Population Growth (annual \%) & 37 & --- & --- & --- & --- & --- & --- & -- \\
\hline 10 & 205 & $\mathrm{DP}$ & Total Population & --- & -- & -- & --- & --- & --- & --- & -- \\
\hline 11 & 204 & DP & Urban Population (\% of total) & --- & -- & -- & --- & --- & -- & --- & -- \\
\hline 12 & 179 & $A \& L$ & $\begin{array}{l}\text { Ease of doing business index }(1=\text { most business-friendly } \\
\text { regulations) }\end{array}$ & 29 & --- & --- & --- & --- & --- & $\mid---$ & --- \\
\hline 13 & 134 & A\&L & $\begin{array}{c}\text { Normalized investment in telecoms with private participation } \\
\text { (current US\$/person) }\end{array}$ & --- & --- & --- & --- & --- & --- & $\mid---$ & --- \\
\hline 14 & 76 & $\mathbf{C \& E}$ & CPIA gender equality rating ( $1=$ low to $6=$ high $)$ & --- & --- & --- & --- & --- & --- & --- & -- \\
\hline 15 & 76 & $\mathbf{C \& E}$ & $\begin{array}{l}\text { CPIA property rights and rule-based governance rating (1=low } \\
\text { to } 6=\text { high })\end{array}$ & 36 & --- & --- & --- & --- & -- & --- & --- \\
\hline 16 & 101 & $\mathrm{E} \& \mathrm{I}$ & Researchers in $\mathrm{R} \& \mathrm{D}$ (per million people) & 20 & 29 & 30 & 38 & 39 & --- & --- & --- \\
\hline 17 & 186 & $\mathbf{E} \& \mathbf{I}$ & Scientific and technical journal articles & 18 & 34 & -- & --- & --- & -- & --- & -- \\
\hline 18 & 137 & $\mathrm{E} \& \mathrm{I}$ & Patent applications, residents & --- & --- & --- & --- & --- & --- & --- & --- \\
\hline 19 & 165 & E\&I & Trademark applications, total & 34 & -- & -- & -- & --- & --- & --- & -- \\
\hline 20 & 79 & $\mathrm{E} \& \mathrm{I}$ & Technicians in R\&D (per million people) & 29 & 30 & 38 & 39 & --- & --- & --- & --- \\
\hline 21 & 147 & $\mathrm{E} \& \mathrm{I}$ & Expenditure per student, primary (\% of GDP per capita) & 22 & --- & --- & --- & --- & --- & --- & --- \\
\hline 22 & 145 & $\mathrm{E} \& \mathrm{I}$ & Expenditure per student, secondary (\% of GDP per capita) & --- & --- & --- & --- & --- & --- & --- & --- \\
\hline 23 & 138 & $\mathbf{E} \& \mathbf{I}$ & Expenditure per student, tertiary ( $\%$ of GDP per capita) & --- & -- & -- & --- & --- & -- & --- & -- \\
\hline 24 & 117 & $\mathrm{E} \& \mathrm{I}$ & Labor force with primary education ( $\%$ of total) & --- & --- & --- & --- & --- & --- & --- & --- \\
\hline 25 & 115 & $\mathbf{E} \& \mathbf{I}$ & Labor force with secondary education (\% of total) & --- & -- & -- & --- & --- & -- & --- & -- \\
\hline 26 & 115 & $\mathrm{E} \& \mathrm{I}$ & Labor force with tertiary education ( $\%$ of total) & -- & -- & -- & --- & --- & --- & --- & -- \\
\hline 27 & 197 & $\mathbf{A} \& \mathbf{L}$ & $\begin{array}{c}\text { Normalized International tourism, number of arrivals / total } \\
\text { population }\end{array}$ & 28 & --- & --. & $\mid--$ & --- & --- & --- & --- \\
\hline 28 & 123 & $A \& L$ & $\begin{array}{l}\text { Normalized International tourism, number of departures / total } \\
\text { population }\end{array}$ & 29 & --- & --- & --- & --- & --- & --- & --- \\
\hline 29 & 200 & E\&I & Internet users (per 100 people) & 30 & 32 & 38 & 39 & --- & --- & --- & --- \\
\hline 30 & 128 & $\mathrm{E} \& \mathrm{I}$ & Daily newspapers (per 1,000 people) & 32 & 38 & 39 & --- & --- & --- & --- & -- \\
\hline 31 & 74 & $\mathrm{E} \& \mathrm{I}$ & $\begin{array}{l}\text { Information and communication technology expenditure (\% of } \\
\text { GDP) }\end{array}$ & --- & --- & --- & --- & $\mid---$ & --- & |--- & --- \\
\hline 32 & 178 & $\mathrm{E} \& \mathrm{I}$ & Normalized Air transport, passengers carried / total population & 39 & --- & --- & --- & --- & --- & --- & --- \\
\hline 33 & 108 & $\mathbf{E} \& \mathbf{I}$ & Railways, passengers carried (million passenger-km) & --- & -- & -- & --- & --- & --- & --- & -- \\
\hline 34 & 63 & E\&I & Roads, passengers carried (million passenger-km) & --- & --- & --- & --- & --- & --- & --- & --- \\
\hline 35 & 205 & DP & Population density (people per sq. km) & --- & -- & -- & --- & --- & -- & --- & -- \\
\hline 36 & 117 & $\mathrm{DP}$ & Population in the largest city ( $\%$ of urban population) & --- & --- & --- & --- & --- & --- & --- & --- \\
\hline 37 & 204 & DP & Urban population growth (annual \%) & --- & --- & --- & --- & --- & --- & --- & --- \\
\hline 38 & 202 & $\mathbf{E} \& \mathbf{I}$ & Telephone lines (per 100 people) & 39 & -- & -- & --- & --- & --- & --- & -- \\
\hline 39 & 198 & WE\&T & GDP per capita (current US\$) & --- & -- & -- & --- & --- & -- & --- & -- \\
\hline 40 & 182 & WE\&T & $\begin{array}{c}\text { Imports and Exports of goods, services and income (BoP, current } \\
\text { US\$) per captia / gdpCap }\end{array}$ & 41 & --- & --- & --- & \begin{tabular}{|l}
-- \\
\end{tabular} & --- & $\mid---$ & -- \\
\hline 41 & 181 & WE\&T & Imports and Exports of ICT (BoP, current US\$) per captia / gdpCap & --- & --- & --- & --- & --- & --- & --- & --- \\
\hline
\end{tabular}




\section{FIGURES}

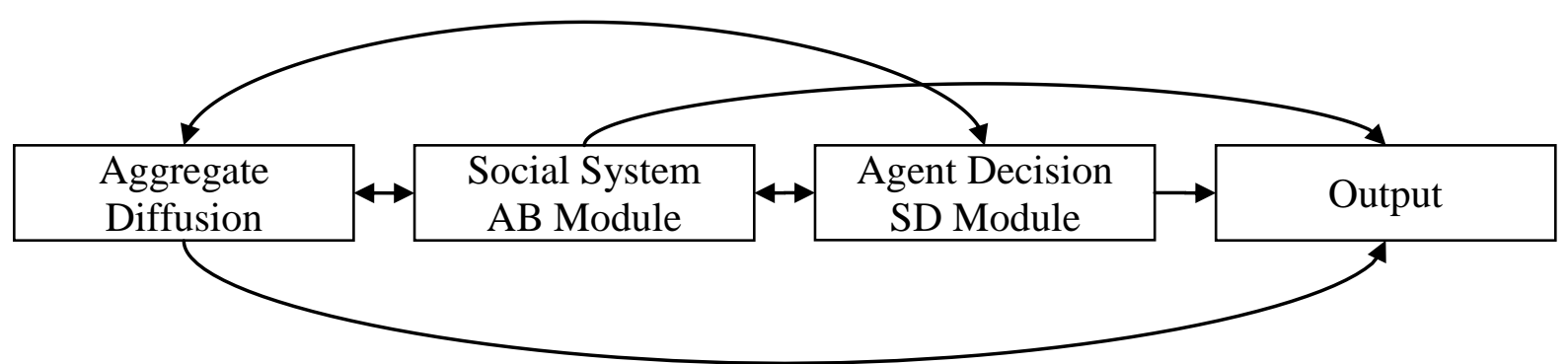

Fig. 1. Architectural design of the hybrid AB-SD model; an integrated class comprising three modules.

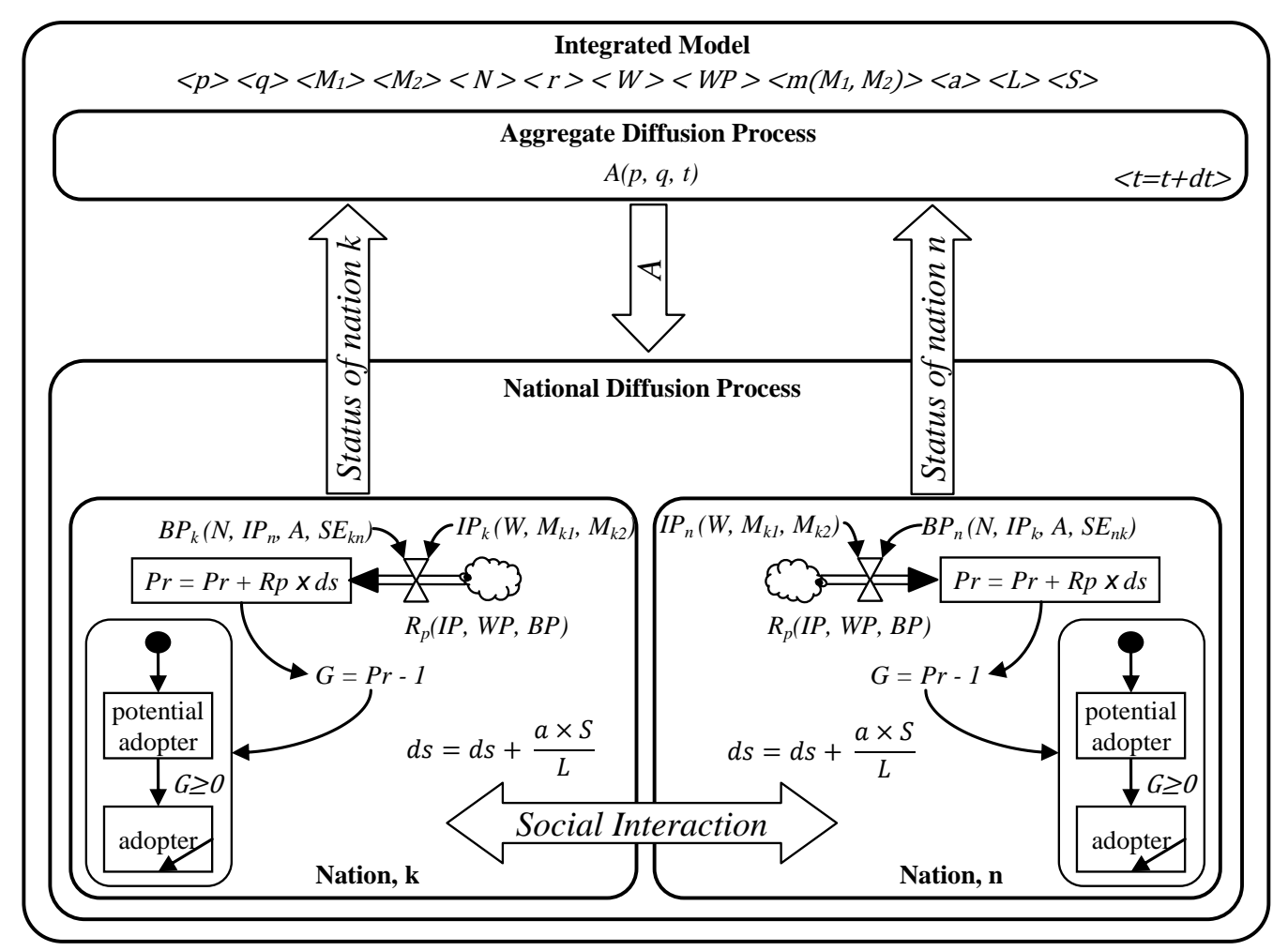

Fig. 2. Implementation of a hybrid AB-SD model for the international diffusion of technological innovation, showing only two nations. 




Fig. 3. Aggregate international diffusion curves for nine technologies as a function of system age.

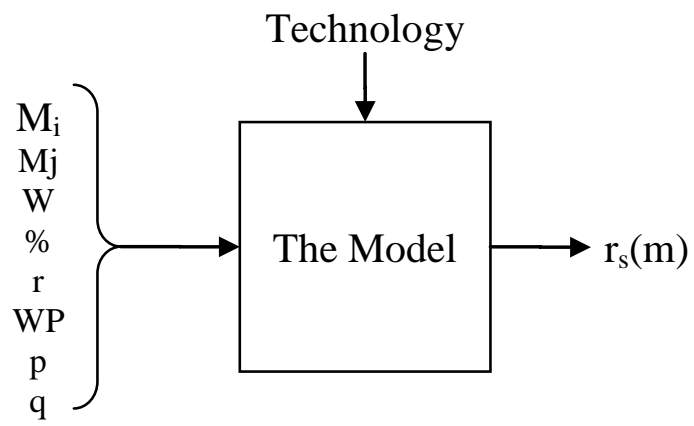

Fig 4. Illustration of the optimization task. 